\title{
Microstructural Characterization of Boride Layers on Gray Cast Iron and Ductil Cast Iron by Dehydrated Paste-Pack Boriding
}

\author{
M Ortiz-Domínguez ${ }^{1 *}$, A Cruz-Avilés ${ }^{1}$, I Morgado-Gonzalez $^{1}$, E Cardoso-Legorreta ${ }^{1}$, OA Gómez- \\ Vargas $^{2}, \mathrm{~J} \mathrm{Solis-Romero}^{2}$, VA Castellanos-Escamilla ${ }^{1}$ and E Coronel-Guerra ${ }^{1}$ \\ 1. Department of Mechanical Engineering, Universidad Autónoma del Estado de Hidalgo-Campus \\ Sahagún, Hidalgo, México. \\ 2. Research and Postgraduate Division, Instituto Tecnológico de Tlalnepantla, EdoMéx, México. \\ * Corresponding author:martin_ortiz@uaeh.edu.mx.edu
}

Today hard coatings are playing an important role in the wear protection for cutting and forming tools and on automotive components. For example, from 1985 to 2000 economic losses in Germany were adding up to approximately $2-3 \%$ of the gross national product. In particular boriding is a thermochemical diffusion-based surface-hardening process that can be applied to a wide variety of ferrous, nonferrous, and cermet materials. One basic advantage is that iron boride layers have extremely high hardness values (between 1600 and $2000 \mathrm{HV}$ ) [1]. In this study, the microstructure of the double phase layer $\left(\mathrm{FeB}+\mathrm{Fe}_{2} \mathrm{~B}\right)$ and single phase layer $\left(\mathrm{Fe}_{2} \mathrm{~B}\right)$ have been investigated at different temperatures by the dehydrated paste-pack boriding method on the surface of gray cast iron and ductil cast iron. Gray cast iron is a hard brittle material with excellent damping characteristics and good machinability. This is due to graphite flakes which precipitate into the iron during solidification. Ductile cast iron is a unique engineering alloy that is similar to gray iron except that it is not brittle. The material is able to flex and has more fatigue resistance than gray iron. These properties are a result of creating graphite nodules instead of graphite flakes during solidification. Ductile iron boasts more strength and flexibility than gray iron while also featuring impact resistance. Boriding heat treatment was carried out by using dehydrated paste-pack boriding method that is similar to pack carburizing process. Boriding mixture contains of $\mathrm{B}_{4} \mathrm{C}$ (active source of boron), $\mathrm{Na}_{3} \mathrm{AlF}_{6}$ (activator), $\mathrm{SiC}$ (inert filler), and $\mathrm{SiC}_{8} \mathrm{H}_{20} \mathrm{O}_{4}$ which is used to protect surfaces. All samples to be borided were packed in the powder mix and sealed in a stainless steel container. The powder-pack boriding process was carried out in a conventional furnace under a pure argon atmosphere at 1123 and $1273 \mathrm{~K}$ for $8 \mathrm{~h}$ of exposure for each temperature. Once the boriding treatment was finished the container was removed from the furnace and slowly cooled to room temperature. The hard samples were cross-sectioned and resin-embedded for traditional metallographic preparation; were grinded with $\mathrm{SiC}$ abrasive paper up to grit 2500. Afterwards, the samples were polished using a diamond suspension with particle size of $6 \mu \mathrm{m}$, finishing with particle size of $3 \mu \mathrm{m}$, then the polished samples were etched in a $2 \%$ nital solution to observe the boride layer depths formed on the surface of gray cast iron and ductil cast iron. The boride layer depths and morphology were analysed by Scanning Electron Microscopy (SEM), Energy Dispersive Spectroscopy (EDS) and X-ray diffraction (XRD) patterns were collected on the surface of the borided gray cast iron and ductil cast iron. Figures 1 and 2 show the cross-sections of boride layers formed on the surface of gray cast iron and ductil cast iron at $1123 \mathrm{~K}$ for $8 \mathrm{~h}$ of exposure time respectively. The resultant microstructure of a singlephase layer ( $\mathrm{Fe}_{2} \mathrm{~B}$ only) layers looks very dense, compact and homogenous, with sawtooth morphology. This particular morphology is ascribed to the presence of carbon and alloying elements in gray cast iron (see Fig. 1). Likewise, the formation of a double-phase layer $\left(\mathrm{FeB}+\mathrm{Fe}_{2} \mathrm{~B}\right)$ was revealed with a flat morphology in ductil gray cast iron (see Fig. 2). This particular morphology is attributed to the presence of the alloying elements in the substrate of ductil cast iron and can be explained by the existence of activated diffusion pathways in the $\mathrm{Fe}_{2} \mathrm{~B}$ and $\mathrm{FeB}$ crystal lattices. It is known that the alloying elements 
modify the morphology of $\left(\mathrm{FeB} / \mathrm{Fe}_{2} \mathrm{~B}\right.$ and $\mathrm{Fe}_{2} \mathrm{~B} /$ substrate $)$ interfaces and tend to concentrate at the tips of the boride needles by generating a flat morphology. The results of XRD studies presented in Fig. 3a and Fig. $3 b$ show the XRD pattern recorded on the surface of borided gray cast iron and ductil cast iron, respectively. They confirm that iron diboride $\left(\mathrm{Fe}_{2} \mathrm{~B}\right)$ on the surface of borided gray cast iron. Likewise, the diffraction peaks relative to the iron boride $(\mathrm{FeB})$ and the iron diboride $\left(\mathrm{Fe}_{2} \mathrm{~B}\right)$ are easily identified on the surface of borided ductil cast iron. The EDS analysis obtained by SEM at the $\mathrm{Fe}_{2} \mathrm{~B}$ layer for the borided gray cast iron is shown in Fig. $4 \mathrm{a}$ and for the borided ductil gray cast iron is shown in Fig. 4b at the $\mathrm{FeB} / \mathrm{Fe}_{2} \mathrm{~B}$ interphase. These results demonstrate that the dehydrated paste-pack method applied to gray cast iron and ductil cast iron formed a single phase layer $\mathrm{Fe}_{2} \mathrm{~B}$ or a double phase layer $\left(\mathrm{FeB}+\mathrm{Fe}_{2} \mathrm{~B}\right)$ depending on the chemical composition.

References:

[1] A Graf von Matuschka in "Boronizing“, $1^{\text {st }}$ ed. (Carl Hanser Verlag, Munich) p. 12.

[2] JR Davis in "Surface Hardening of Steels: Understanding the Basics", 1 st ed. (ASM, Ohio) p. 213.

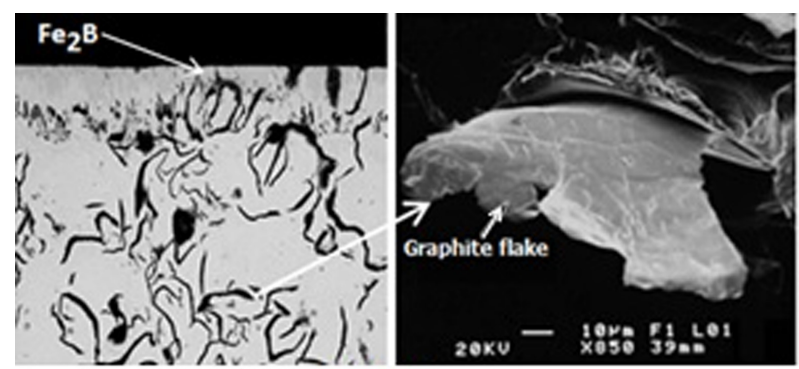

Fig. 1

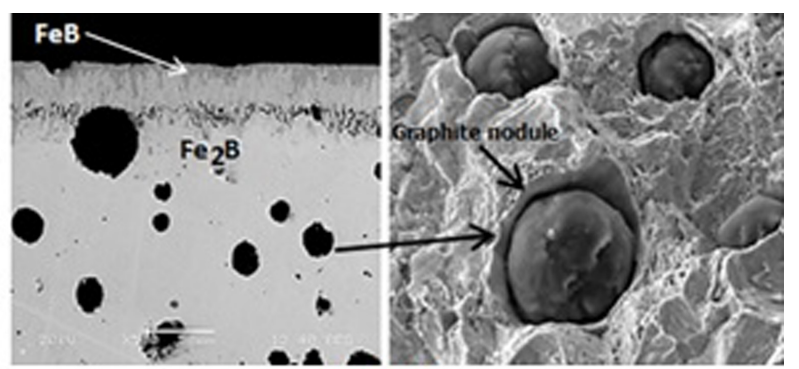

Fig. 2

Figure 1. Image (SEM) cross-sectional of borided gray cast iron and SEM cross-sectional of borided ductil cast iron (Figure 2.) at $1123 \mathrm{~K}$ for 8 hours of treatment.

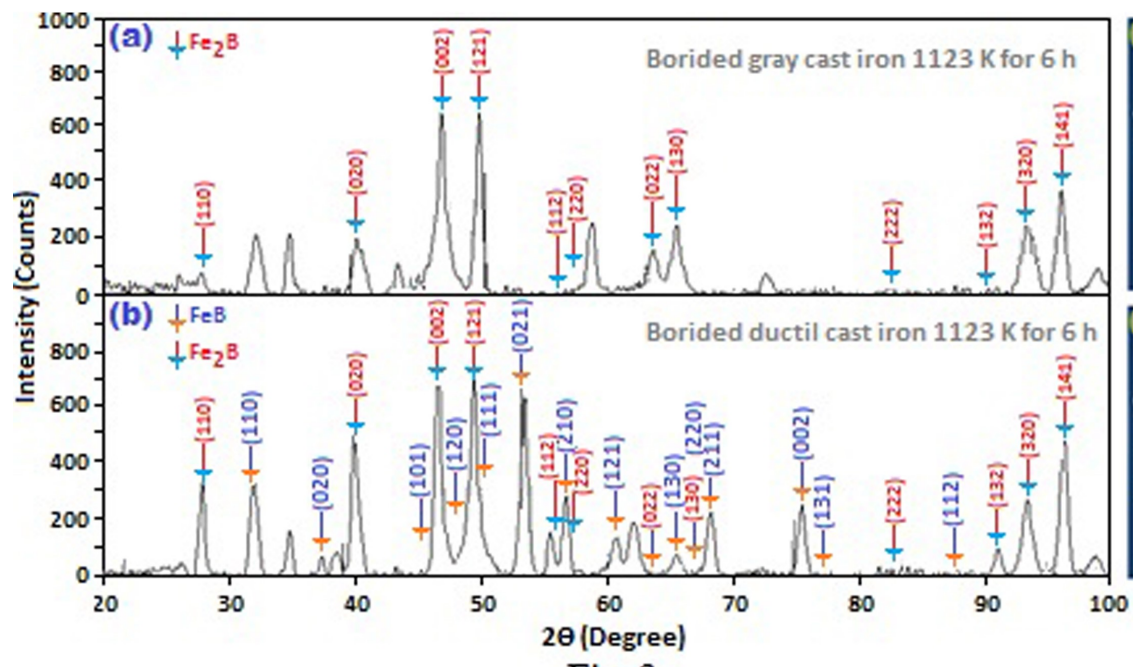

Fig. 3


Fig. 4

Figure 3. XRD diffraction patterns of: (a) borided gray cast iron and (b) ductil cast iron at $1273 \mathrm{~K}$ for 8 hours and EDS spectrum of borided samples at interfaces: (a) borided gray cast iron and (b) ductil cast iron at $1123 \mathrm{~K}$ for 8 hours of treatment (Figure 4.). 